ENTREPRENEURSHIP AND SUSTAINABILITY ISSUES

ISSN 2345-0282 (online) http://jssidoi.org/jesi/ 2019 Volume 7 Number 1 (September) http://doi.org/10.9770/jesi.2019.7.1(5)

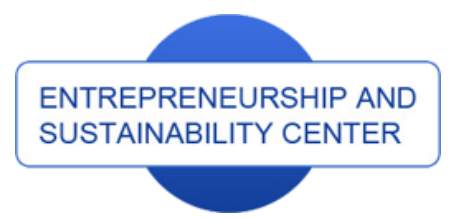

Publisher

http://jssidoi.org/esc/home

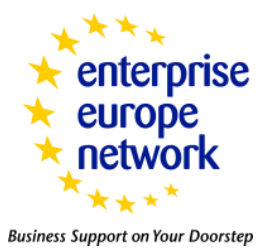

CASPA

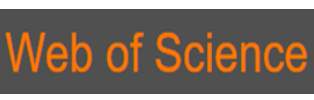

\title{
POLITICAL CONNECTION, BLOCKHOLDER OWNERSHIP AND PERFORMANCE*
}

\author{
Lela Nurlaela Wati ${ }^{1}$, Hj. Ina Primiana ${ }^{2}$, Kashan Pirzada ${ }^{3}$, Rachmat Sudarsono ${ }^{4}$ \\ ${ }^{I}$ STIE Muhammadiyah Jakarta, Jalan Minangkabau No. 60 Jakarta Selatan, Indonesia. \\ ${ }^{2}$ Universitas Padjadjaran, Bandung, Indonesia \\ ${ }^{3}$ Tunku Puteri Intan Safinaz School of Accountancy, Universiti Utara Malaysia, Kedah, Malaysia \\ ${ }^{4}$ Universitas Padjadjaran, Bandung, Indonesia
}

Ilela_nwm@yahoo.com; lela@stiemj.ac.id ${ }^{2}$ ina.sagir@fe.unpad.ac.id ${ }^{3}$ kashan@uum.edu.my ${ }^{4}$ asfar_jati@yahoo.com

Received 27 February 2019; accepted 30 June 2019; published 30 September 2019

\begin{abstract}
This paper aims to examine the effect of blockholder of political connected firm on the performance of conglomerates. The sample of this paper is all 66 conglomerates listed on the Indonesia Stock Exchange from 2006 to 2014. Regression panel data with General Least Square was used for this analysis. It was found that Family and state blockholder have positive and significant effect on firm value at all cut off (10\%-50\%), political connections in the family, state, and public blockholder have significant positive effect on firm value. The result of this paper indicates that the structure of companies' ownership has contribution to determine the political connections in the conglomerates. The concentration of ownership in the company and family as controlling highest conglomerate in Indonesia as well as their involvement in politics implies that Indonesia has fallen into oligarchy state, in which the rules are held by a group of wealthy political elites.
\end{abstract}

Keywords: firm value; political connection; blockholder; Indonesia

Reference to this paper should be made as follows: Wati, L.N.; Primiana, H.I.; Pirzada, K.; Sudarsono, R. 2019. Political connection, blockholder ownership and performance, Entrepreneurship and Sustainability Issues 7(1): 52-68. http://doi.org/10.9770/jesi.2019.7.1(5)

JEL Classifications: M40. M41. M49

Additional disciplines: law; political sciences; sociology; information and communication

\footnotetext{
* This research was supported by Directorate of General for Strengthening Research and Development, the Ministry of Research and Technology Republic Indonesia, Higher Education (DIKTI) for providing Doctoral Scholarship and Sekolah Tinggi Ilmu Ekonomi Muhammadiyah Jakarta Indonesia.
} 


\section{ENTREPRENEURSHIP AND SUSTAINABILITY ISSUES}

ISSN 2345-0282 (online) http://jssidoi.org/jesi/ 2019 Volume 7 Number 1 (September) http://doi.org/10.9770/jesi.2019.7.1(5)

\section{Introduction}

In developing countries, conglomerates have strong position due to the concentration of economic power in the hands of a small group of large conglomerates (Claessens et al., 1999). Likewise, the conditions that occur in Indonesia is similar, where the company contributes huge portion to GDP Indonesian conglomerate. With a small number (only $0.01 \%$ ) of the total companies in Indonesia, they contribute enormously to the GDP of Indonesia at 44.4\% (BPS, 2009). In fact, of the total 510 companies listed on the Indonesia Stock Exchange in 2014, there were 116 conglomerate's companies in the Indonesia Stock Exchange which control more than 70\% of the total market capitalization of the Stock Exchange (Wati et al., 2016a). In the period of 2006 - 2014, they dominate the market capitalization which consecutively account for $76.25 \%, 77.62 \%, 76.10 \%, 78.88 \%, 75.24 \%, 68.46 \%$, $74.45 \%, 72.35 \%$ and $71.61 \%$.

In 2009, the capitalization of conglomerate increased by $94.46 \%$. Likewise, in 2014 alone, their capitalization increased by $22.66 \%$ from the previous year and the highest value for the whole year of observations. Increased conglomerate's capitalization in 2009 was attributed to significant increase and improvements in economic conditions after the global crisis which was predicted by the legislative and presidential elections in Indonesia. This phenomenon is amplified by the increasing market value of companies in the enterprise political connections with the winner of the election party and the president, especially in large companies and state-owned enterprises. The condition shows that the entrepreneurs and corporate leaders in developing countries such as Indonesia where the level of corruption is still high, are believed to have political connections that provide benefits to achieve the companies' objectives. Hence, they strive to foster political connections in order to achieve the growth of the company since they realize that the political connections are a valuable resource (Fisman, 2001; Li et al., 2012). In the countries with weak legal system and the high level of corruption, political connections are very valuable to the company; even these aspects are not inseparable in the country which has a strong legal system such as in the USA (Goldman et al., 2009). in their study, they found that political connections have a broad effect on the value of the firm in the United States Presidential Election in 2000 and a parliament member who won by Republican Party. Likewise, Faccio (2006) supported the findings of Goldman et al. (2009), using a sample of 47 countries, he documented that political connections are very common in countries with high levels of perceived corruption, even samples of first ranked companies in Indonesia have the largest political connections with members of parliament (DPR), ministers, president, and relations relatives. This condition is underpinned by the structure of corporate ownership in Indonesia which are concentrated and controlled by the family. These conditions are inseparable from companies' conglomerate. La Porta et al., 1999; Claessens et al., 2000; Lukviarman, 2004; Kim, 2006; and Siregar, 2006, proved that companies in Indonesia have concentrated ownership structure in the family. There are various researches on conglomerates in some countries encouraging writer's interest in investigating the conglomerates in Indonesia, as well as many businessmen who get involved in politics. To the author's best knowledge; there are few researchers who conducted extensive study on the conglomerate in Indonesia. The results of this present research shows that the political connection on family controlling and state block holder have a positive and significant effect on firm value (Tobin's Q and Return on Assets).

The rest of this paper is structured as follows: After the introduction, Section 2 discusses important literature on this topic an examination of relevant theories as well as hyphoteses development, while section 3 elaborates on research methodology. Section 4 discusses major findings of the study and finally in section 5, paper is summarised and concluded.

\section{Literature Review}

According to Dicko (2017) the basic presupposition of agency theory is the separation of management and ownership. In the classic economic model, capitalist companies are supposed to be owned by several shareholders scattered across the market, each of whom hold a small share. The shareholders then hire a professional manager 


\section{ENTREPRENEURSHIP AND SUSTAINABILITY ISSUES}

ISSN 2345-0282 (online) http://jssidoi.org/jesi/ 2019 Volume 7 Number 1 (September) http://doi.org/10.9770/jesi.2019.7.1(5)

who, in return for a substantial payment, is supposed to ensure that shareholders get a return on their investment. Given the opportunistic nature of human beings, manager can act in their own interest at the expense of shareholders to maximize their own personal utility - hence the potential conflicts of interest between shareholders and management and the resulting cost.

Claessens et al. (2000) mentioned that the block holder in Indonesia is controlled by the family, the state and financial institutions. Furthermore, Siregar (2006) supported the findings of Claessens et al. (2000), in which it is stated the cut-off $10 \%-50 \%$ concentration of ownership in Indonesia is $99.09 \%, 95.36 \%, 89.95 \%, 79.83 \%$, and $68.04 \%$, respectively. Family as a block holder is not only found in developing countries, but it is also common in developed countries even though there are still many companies that are controlled by the family (Faccio et al., 2001). Arifin (2003) and Siregar (2006) also proved that the block holder of a public company is mostly controlled by the family of Indonesia. Arifin (2003) stated that the family is a primary owner of a public company in Indonesia. These findings are consistent with the study results of La Porta et al. (1999), and Claessens et al. (2000) which stated that the family dominates ownership of public companies.

Based on the literature review and previous researches regarding the block holder, especially in Indonesia, Hypothesis 1 is formulated as follows:

$\mathrm{H}_{1 \mathrm{a}}$ : The family block holders have positive effect to the conglomerate performance.

$\mathrm{H}_{1 \mathrm{~b}}$ : The institutions block holders have positive effect to the conglomerate performance.

$\mathrm{H}_{1 \mathrm{c}}$ : The state block holders have positive effect to the conglomerate performance.

$\mathrm{H}_{1 \mathrm{~d}}$ : The public firm block holders have positive effect to the conglomerate performance.

The ownership structure of the company has a contribution in determining the political connections (Wati et al., 2015). This is evidenced by Boubakri et al. (2008), resulting that political connections in the company are positively related to the rest of government ownership, and are negatively related to foreign ownership. On the other hand, Tian and Cheung (2013) documented the different results, where political connections in China can increase the value of firms controlled by the family, but the political connections do not significantly affect the value of firms controlled by the government. Political connections of the company controlled by the family have better access to bank loans, tax rebates and subsidies granted by the government compared to those controlled by the government (Tian and Cheung, 2013). When the block holder is a family which has political connection, it is likely to dominate the board of directors so that they can make a deal with government officials and enjoy exclusive privileges among them (Chen et al., 2011).

The company has political connection if one of the shareholders or the top management of the company is a member of parliament, ministers or heads of state, or who have a close relationship with political party officials (Faccio, 2006: 370).

Political connections would be more effective in the conditions of high levels of corruption and weak regulation, for both small companies and large companies (Faccio, 2006; Do et al., 2013). Wong (2010) proved that the company experienced an increase in ROE and MBV ratio after joining the Selection Committee. This means that political connections are able to improve the company's performance as measured by ROE and MBV Ratio. In addition, Do et al. (2013) supported research Wong (2010), stating that political connections are able to increase the value of the company at the state level.

Although various profits can be gained by corporate politically connected, political connections had a negative impact on the company, namely high leverage followed by overinvestment (Wu et al., 2012), the decline in stock prices and stock returns (Fisman, 2001; Fan et al., 2007), the decline in performance of the company (Leuz and Gee, 2006; Xu and Zhou, 2008; Li and Xia, 2013), the poor quality of financial report (Chaney et al., 2011). 


\section{ENTREPRENEURSHIP AND SUSTAINABILITY ISSUES}

ISSN 2345-0282 (online) http://jssidoi.org/jesi/ 2019 Volume 7 Number 1 (September) http://doi.org/10.9770/jesi.2019.7.1(5)

Deng et al. (2012) examined the effect of diversification in the companies which have political connection and its influence on companies in China. They found that political connections have a positive and significant impact on the performance of the company. The influence of political connections on conglomerate (unrelated diversification) is stronger than the related diversification. However, politically connected conglomerate (unrelated diversification) will have a negative impact on the performance of the company in the future (longterm) which can harm the company. The company which has a market value of political connection tend to diversify in unrelated field (unrelated diversification).

Supporting the findings of Deng et al. (2012), Ang et al. (2013) examined the companies politically connected in Singapore. They found that within three years after the IPO, most of companies which were previously independent from political connections, but, after the sample was broken down into several categories of industry, it was found the director of the company had political connection and positive and significant impact on the value of the firm.

Based on the systematic review of previous researches, it is found that, positive influence of political connections on firm value (Johnson and Mitton, 2003; Faccio, 2006; Goldman et al .; 2006; Boubakri et al., 2008; Wong, 2010; Cooper et al ., 2010; Ang et al., 2013; Do et al., 2013). It is supported by the study results of Li et al. (2012) which showed a strong positive correlation between political connections and the company diversification. Political connections can be more impactful for the company diversified in unrelated fields (conglomerate). Deng et al. (2012) supported the findings of $\mathrm{Li}$ et al. (2012), confirming that the performance of conglomerate (unrelated diversification) which has political connection is better than that of the company which has political connection with related diversification. Wati et al (2016b) and Wati (2017) showed positive effect between political connections on conglomerate performance (accounting and market performance). These results indicate that political connections to the conglomerate are more valuable than non-conglomerate.

According to Pirzada et al. (2015) the role of the block holder in a strong political connection already stated above, according to the author's best knowledge, there still lack of research which examines and focuses on the role of block holder (family, institution, state and public firm) and the influence of political connections on the performance or value of conglomerate. Based on the empirical explanation mentioned above and examining the phenomenon of the ownership structure in Indonesia, Hypothesis 2 is formulated as follows:

$\mathrm{H}_{2 \mathrm{a}}$ : Political connections at the family blockholder have a positive effect on the conglomerate performance;

$\mathrm{H}_{2 \mathrm{~b}}$ : Political connections at the institution blockholder have a positive effect on the conglomerate performance;

$\mathrm{H}_{2 \mathrm{c}}$ : Political connections at the state blockholder have a positive effect on the conglomerate performance;

$\mathrm{H}_{2 \mathrm{~d}}$ : Political connections at the company controlled by public firm have a positive effect on the conglomerate performance.

\section{Research Methodology}

The present study used secondary data from the period of 2006 - 2014 based on published annual report. The research sample is all conglomerates listed on the Indonesia Stock Exchange since 2006 which publish annual financial reports and never delisting from the capital market. Based on these criteria, the total of conglomerate accounted for 72 companies, from which it can be processed as many as 66 companies (2006-2014), so that the total samples observed in this study were 594.

The variables used in this research were conglomerate performance, political connection, and block holder. Conglomerates performance in this paper used a market-based approach (market performance) and profit-based approach (accounting performance) (Niessen \& Ruenzi, 2007; Deng et al., 2012). Market performance indicators used the proxy of Tobin's Q and profit-based approach (accounting performance) used the proxy of Return on Assets (Niessen \& Ruenzi, 2007; Deng et al., 2012). 
Meanwhile, the political connection used a number of criteria according to Fisman, 2001; Leuz dan Gee, 2006; Faccio, 2006. In regard with the criteria, it is defined if one of the shareholders or top management of the companies is a member of parliament, ministers or heads of state, or who have a close relationship with them from political party officials, the army and police officials. The member of parliament, ministers, or former heads

To ensure that the model used to test the hypotheses as mentioned in the previous paragraph applies to all conglomerates, the variable of firm size, age and growth as a control variable were used. The following table (Table 1) explains the operationalization of variables.

Table 1. Description of Variables

\begin{tabular}{|c|c|}
\hline Variables & Description \\
\hline $\begin{array}{l}\text { Performance Measure: } \\
\text { Return on Assets } \\
\text { Tobin's Q } \\
\text { Independent Variable: } \\
\text { Political Connection } \\
\text { Ownership Variables: } \\
\text { Family } \\
\text { Institutional (finance) } \\
\text { State } \\
\text { Public firm } \\
\text { Blockholder of cut off } 10 \% \\
\text { Blockholder of cut off } 20 \% \\
\text { Blockholder of cut off } 30 \% \\
\text { Blockholder of cut off } 40 \% \\
\text { Blockholder of cut off } 50 \% \\
\text { Control Variables: } \\
\text { Firm Size } \\
\text { Growth } \\
\text { Firm Age }\end{array}$ & $\begin{array}{l}\text { Ratio of profit after tax to total assets } \\
\text { Ratio of the market capitalization plus debt divided the total assets } \\
\text { Dummy Variable: } \\
1=\text { political connected; } 0=\text { nonpolitical connected } \\
\text { Dummy Variable } \\
1=\text { if the firm has family Blockholder, } 0=\text { otherwise } \\
1=\text { if the firm has institutional Blockholder, } 0=\text { otherwise } \\
1=\text { if the firm has state blocholder, } 0=\text { otherwise } \\
1=\text { if the firm has public firm blocholder, } 0=\text { otherwise } \\
1=\text { if the blocholder owns }(10-20 \%) \text { of the shares, } 0=\text { otherwise } \\
1=\text { if the blocholder owns }(20-30 \%) \text { of the shares, } 0=\text { otherwise } \\
1=\text { if the blocholder owns }(30-40 \%) \text { of the shares, } 0=\text { otherwise } \\
1=\text { if the blocholder owns }(40-50 \%) \text { of the shares, } 0=\text { otherwise } \\
1=\text { if the blocholder owns }(>50 \%) \text { of the shares, } 0=\text { otherwise } \\
\text { Log of Total Assets } \\
\text { Ratio of } \Delta \text { Total Sales to total sales } \\
\text { Number of years since incorporation }\end{array}$ \\
\hline
\end{tabular}

In this study, a block holder is defined according to La Porta et al (1999), Claessens et al (2000), Faccio and Lang (2002), Arifin (20030, Siregar (2006), as families, financial institutions, state enterprises, and public company owned by people at the level of control rights which are $10 \%-50 \%$ (cut off).

To test the hypotheses in the study, regression model with General Least Square was used as follows: Hypotheses 1 testing used Model 1

Tobin' $s Q_{i t}=\alpha 1+\beta 1$ Famit $+\beta 2$ Instit $+\beta 3$ Stateit $+\beta 4$ Tbkit $+\beta 5$ Sizeit $+\beta 6$ Growthit $+\beta 7$ Ageit $+\varepsilon 1 \ldots(1)$

ROA it $=\alpha 2+\beta 8$ Famit $+\beta 9$ Instit $+\beta 10$ Stateit $+\beta 11$ Tbkit $+\beta 12$ Sizeit $+\beta 13$ Growthit $+\beta 14$ Ageit $+\varepsilon 2 \ldots$

Hypotheses 2 testing used Model 2

Tobin' sQ $i t=\alpha 1+\beta 1$ Pol $^{*}$ Famit $+\beta 2 \mathrm{Pol}^{*}$ Instit $+\beta 3 \mathrm{Pol}^{*}$ State it $+\beta 4 \mathrm{Pol}^{*}$ Tbkit $+\beta 5$ Size it $+\beta 6 \mathrm{Growth}$ it $+\beta 7$ Age it $+\varepsilon 3 \ldots$... (3) ROA it $=\alpha 2+\beta 8$ Pol $*$ Famit $+\beta 9$ Pol $*$ Instit $+\beta 10$ Pol $*$ Stateit $+\beta 11$ Pol $*$ Tbkit $+\beta 12$ Sizeit $+\beta 13 G r o w t h i t+\beta 14 A g e i t+\varepsilon 4 \ldots(4)$ 


\section{Results}

\subsection{Descriptive Statistics Analysis}

An overview of research data in 2006 - 2014 shown in Table 2 is presented as follows.

Table 2.

Blockholder Ownership

\begin{tabular}{|c|c|c|c|c|c|c|}
\hline \multirow{2}{*}{ Cut Off } & \multirow{2}{*}{ Year } & \multicolumn{4}{|c|}{ Blockholder Ownership } & \multirow{2}{*}{ Total } \\
\hline & & Family & Institution & State & Public Firm & \\
\hline \multirow{11}{*}{$10 \%$} & 2006 & 54 & 21 & 9 & 11 & 95 \\
\hline & 2007 & 54 & 21 & 10 & 10 & 95 \\
\hline & 2008 & 53 & 24 & 10 & 13 & 100 \\
\hline & 2009 & 53 & 19 & 10 & 13 & 95 \\
\hline & 2010 & 52 & 20 & 10 & 11 & 93 \\
\hline & 2011 & 53 & 27 & 10 & 11 & 101 \\
\hline & 2012 & 52 & 23 & 10 & 10 & 95 \\
\hline & 2013 & 54 & 20 & 10 & 10 & 94 \\
\hline & 2014 & 53 & 20 & 10 & 9 & 92 \\
\hline & Conglomerate & 478 & 195 & 89 & 98 & 860 \\
\hline & Percentage & $55,58 \%$ & $22,67 \%$ & $10,35 \%$ & $11,40 \%$ & $100 \%$ \\
\hline \multirow{11}{*}{$20 \%$} & 2006 & 54 & 14 & 8 & 9 & 85 \\
\hline & 2007 & 51 & 14 & 9 & 9 & 83 \\
\hline & 2008 & 52 & 13 & 9 & 10 & 84 \\
\hline & 2009 & 51 & 15 & 9 & 10 & 85 \\
\hline & 2010 & 50 & 11 & 9 & 9 & 79 \\
\hline & 2011 & 49 & 12 & 9 & 9 & 79 \\
\hline & 2012 & 48 & 13 & 9 & 9 & 79 \\
\hline & 2013 & 49 & 9 & 9 & 9 & 74 \\
\hline & 2014 & 49 & 8 & 9 & 9 & 74 \\
\hline & Conglomerate & 453 & 109 & 80 & 82 & 724 \\
\hline & Percentage & $62,57 \%$ & $15,06 \%$ & $11,05 \%$ & $11,33 \%$ & $100 \%$ \\
\hline \multirow{11}{*}{$30 \%$} & 2006 & 46 & 7 & 8 & 6 & 67 \\
\hline & 2007 & 43 & 6 & 9 & 6 & 64 \\
\hline & 2008 & 47 & 6 & 9 & 6 & 68 \\
\hline & 2009 & 48 & 9 & 9 & 6 & 72 \\
\hline & 2010 & 46 & 9 & 9 & 6 & 70 \\
\hline & 2011 & 45 & 10 & 9 & 6 & 70 \\
\hline & 2012 & 45 & 11 & 9 & 7 & 72 \\
\hline & 2013 & 46 & 8 & 9 & 7 & 70 \\
\hline & 2014 & 47 & 7 & 9 & 6 & 69 \\
\hline & Conglomerate & 413 & 73 & 80 & 56 & 622 \\
\hline & Percentage & $66,04 \%$ & $11,74 \%$ & $12,86 \%$ & $9 \%$ & $100 \%$ \\
\hline \multirow{11}{*}{$40 \%$} & 2006 & 44 & 4 & 8 & 5 & 61 \\
\hline & 2007 & 43 & 5 & 9 & 5 & 62 \\
\hline & 2008 & 42 & 4 & 9 & 5 & 60 \\
\hline & 2009 & 40 & 6 & 9 & 5 & 60 \\
\hline & 2010 & 39 & 6 & 9 & 5 & 59 \\
\hline & 2011 & 36 & 7 & 9 & 5 & 57 \\
\hline & 2012 & 38 & 7 & 9 & 6 & 60 \\
\hline & 2013 & 40 & 6 & 9 & 5 & 60 \\
\hline & 2014 & 41 & 5 & 9 & 5 & 60 \\
\hline & Conglomerate & 363 & 50 & 80 & 46 & 539 \\
\hline & Percentage & $67,35 \%$ & 9,28 & $14,84 \%$ & $8,53 \%$ & $100 \%$ \\
\hline \multirow{2}{*}{$50 \%$} & 2006 & 36 & 2 & 8 & 4 & 85 \\
\hline & 2007 & 38 & 3 & 9 & 4 & 83 \\
\hline
\end{tabular}


ENTREPRENEURSHIP AND SUSTAINABILITY ISSUES

ISSN 2345-0282 (online) http://jssidoi.org/jesi/ 2019 Volume 7 Number 1 (September) http://doi.org/10.9770/jesi.2019.7.1(5)

\begin{tabular}{|l|c|c|c|c|c|c|}
\hline & 2008 & 37 & 4 & 9 & 4 & 84 \\
2009 & 35 & 4 & 9 & 4 & 85 \\
2010 & 35 & 5 & 9 & 4 & 79 \\
2011 & 31 & 3 & 9 & 5 & 79 \\
2012 & 33 & 3 & 9 & 6 & 79 \\
2013 & 34 & 2 & 9 & 5 & 76 \\
& 2014 & 37 & 1 & 9 & 5 & 44 \\
& Conglomerate & 316 & 27 & 80 & 41 & $100 \%$ \\
\hline
\end{tabular}

Based on table 2, the data of the conglomerates indicate that family is the main block holder, which accounts for $55.58 \%, 62.56 \%, 66.40 \%, 67.84 \%$, and $68.10 \%$ at cut off $10 \%, 20 \%, 30 \%, 40 \%$, and $50 \%$ respectively. The higher the value of cut off is, the greater the percentage of family ownership will be. It indicates that the family is the main controller in the conglomerate. The results of this study are not much different from the findings of Claessens et al. (2000) who found that $54 \%$ of public companies are controlled by the family at the cut off control rights $10 \%$. Moreover, they found that the highest percentage of the companies controlled by families is in Indonesia, which accounts for $69 \%$. At the cut off $20 \%$, the number of family companies is $53 \%$ and the number of family-controlled companies is mostly in Indonesia, which accounts for $72 \%$. The study results are also supported by the findings of Siregar (2006), who found that the family is the main block holder, which accounts for $55.61 \% 55.55 \%, 55.67 \%, 55.29 \%$, and $53.80 \%$ at the cut off $10 \%, 20 \%, 30 \%, 40 \%$, and $50 \%$ respectively. These results indicate that the majority of conglomerate in Indonesia is controlled by the family. This finding is also consistent with those of La Porta et al. (1999), Faccio and Lang (2001), Arifin (2003), and Siregar (2006) which stated that the family dominates the ownership of public companies.

In addition, based on Table 2 above, at cut off $10 \%-50 \%$, the percentage of the financial institutions which control the companies is $22.67 \%, 15.05 \%, 11.74 \%, 9.35 \%$, and $5.83 \%$ respectively. Meanwhile, the state controls public companies by $10.35 \%, 11.05 \%, 12.86 \%, 14.95 \%$, and $17.24 \%$ respectively. This result is not much different with the findings of Claessens et al. (2000) which stated that the government controls public companies primarily in Singapore and Indonesia by $24 \%$ and $10 \%$ respectively. Likewise, La Porta et al. (1999) found that at the cut off control rights $20 \%$, the average public company controlled by the government is $18 \%$.

A public company is categorized as that controlled by another public company if its largest block holder is a public company owned by the community with the certain level of control rights. Based on Table 2 above, at the cut off $10 \%-50 \%$, the number of public company which is controlled by other public companies accounts for $11.40 \%, 11.33 \%, 9 \%, 8.60 \%$ and $8.84 \%$ respectively. In fact, the results of this study are not much different from that of Claessens et al. (2000) which found that at the cut off of control rights at $10 \%$, 17\%, Asian public companies which are controlled by other public companies with extensive holdings are especially in Philippines (36\%) and Hong Kong (24\%). In Indonesia, there are $17 \%$ of public companies which are controlled by other public companies with extensive holdings. But for the right to control cut off $20 \%$, there are $13 \%$ of public companies which are controlled by other public companies with extensive holdings, especially in Philippines (27\%) and Hong Kong (20\%). On the other hand, in Indonesia, there are 13\% public companies controlled by another public company with extensive holdings.

The greater cut off used, the greater decrease the number of the block holder in the conglomerate will have. However, although the cut off value increases by $20 \%, 30 \%, 40 \%$ and $50 \%$, the concentration of conglomerate ownership in Indonesia still remains high, especially in the controlling family. These results are supported by the finding that the ten family companies in Indonesia during the year of observation dominated the average market capitalization by $30 \%$ out of the total number of public companies in Indonesia. In 2006, with a small number of companies controlled only by 10 families, they dominated the market capitalization accounted for $25.45 \%$ of the 


\section{ENTREPRENEURSHIP AND SUSTAINABILITY ISSUES}

ISSN 2345-0282 (online) http://jssidoi.org/jesi/ 2019 Volume 7 Number 1 (September) http://doi.org/10.9770/jesi.2019.7.1(5)

total companies of 344 . In the year of 2007 , they further dominated the market capitalization of $25.76 \%$ of 383 total companies. Furthermore, in 2008, the market capitalization they dominated was $25.73 \%$ out of 396 total companies. In 2009, the portion increased to $30.44 \%$ of 398 total companies. A year later, the market capitalization they dominated slightly decreased to $29.22 \%$ of 420 companies compared with that of the previous year. In 2011, their domination of market capitalization was at 26.35\% of 440 total companies, while in 2012, they dominated market capitalization by $33.77 \%$ of 462 total companies. In the following year, they dominated the market capitalization by $32.73 \%$ out of 483 companies, and in 2014, their domination on market capitalization was $31.73 \%$ of 510 companies (IDX processed data, 2016).

These findings on that market capitalization is held by ten families is also in agreement with that of Claessens et al., (2000) in which they revealed that the market capitalization in Indonesia is controlled by one family by $16.6 \%$, and a half of the market capitalization in the country is dominated by the ten largest family..The massive accumulation of ownership supports the previous findings revealing that there is a shift of main conflict within the company from a conflict between shareholders and management (Jensen and Meckling, 1976) to a conflict between block holders and minority shareholders in Indonesia (La Porta et al., 1999; Claessens et al. 2000; Lukviarman, 2004; Siregar, 2006).

Table 3 below describes the Tobin's Q, Return on Assets, company size, company growth and firm age in politically connected conglomerate and that which is non-politically connected.

Table 3.

Description of Firm Value and Control Variabel

\begin{tabular}{|l|l|l|l|l|l|l|l|l|}
\hline \multirow{3}{*}{ Variable } & \multicolumn{4}{|c|}{ Panel A } & \multicolumn{4}{c|}{ Panel B } \\
\cline { 2 - 8 } & \multicolumn{3}{|c|}{ Political Connected N=349 } & \multicolumn{3}{c|}{ Non Political Connected N=237 } \\
\cline { 2 - 8 } & Min & Max & Mean & St.Dev & Min & Max & Mean & St.Dev \\
\hline Tobins Q & 0,11 & 17,94 & 1,994 & 2,279 & 0,07 & 11,13 & 1,7 & 1,599 \\
ROA (\%) & -17 & 82 & 8,93 & 11,72 & -29 & 46 & 6 & 11,9 \\
Size (Log) & 5,18 & 8,93 & 7,082 & 0,712 & 4,33 & 7,80 & 6,546 & 0,695 \\
Growth (\%) & -94 & 1071 & 32,75 & 101,48 & -92 & 21.514 & 119,79 & 13.986 \\
Age & 3 & 32 & 15,79 & 5,56 & 1 & 64 & 16,41 & 10,08 \\
\hline
\end{tabular}

Based on Table 3, the average value of Tobin's Q on politically connected companies are larger than those which do not have political connection (1.994> 1.7). Likewise, the average value of Return on Assets in the politically connected companies is higher than those which do not have political connection $(8.93 \%>6 \%)$. The average value of the size of the firm which has political connection is also higher than those which do not have political connection (7.082> 6.546). Meanwhile, the average value of the company's growth which is proxied by sales growth in the politically connected companies is lower than those which do not have political connection (32.75 <119.79). Furthermore, the average age of the firms which have political connection is found to be younger than those which do not have political connection $(15.79<16.41)$. The higher value of Tobins'Q and Return on Assets of the conglomerate which has political connection that that which does not have political connection in Indonesia indicate that the existence of political connections provide benefit to the company.

\subsection{Hypothesis testing and Discussion}

Based on the result of first hypothesis model testing in Table 4 and 5, it shows that the families blockholder have positive effect on the value of the firm both on Tobin's Q and Return on Assets only in the cut off $20 \%, 40 \%$ and $50 \%$ at the significance level of 5\%. Meanwhile, the block holders of financial institutions have negative effect on the value of the firm both on Tobin's Q and Return on Assets at the all cut off ranging from 10\% to 50\%. 
State block holder has significantly positive effect on Tobin's Q and Return on Assets on all cut off 10\%, 20\%, $30 \%, 40 \%$ and $50 \%$ at significance level of $1 \%$. Meanwhile, the block holder of public company has positive effect only on Return on Assets at cut off $20 \%$ - 50\%. Based on the research result by standardized regression analysis (in appendix), state controlling has stronger effect on the value of the firm both in Tobinn's Q and the Return on Assets in all cut off $10 \%$ to $50 \%$ compared to other controllers (family, financial institutions, and public company ). The test result is consistent with the result of robustness test, the result of which shows that the second model is robust.

The result of research on the block holder is in line with Wiwattanakantang (2001); Isik and Soykan (2013); stating that the presence of large shareholder has positive effect on firm value. It means that large shareholder in the company encourages to conduct better monitoring of the manager. This research also proves that large shareholder at the higher ownership level has positive effect on firm value. This finding is in line with the statement of Shleifer and Vishney (1997) which said that company with some of the large shareholders can enable shareholders to monitor each other and also to collaborate to put common interests above their own private interests.

Concentrated ownership can serve as a corporate governance mechanism to perform better monitoring and effective management so that it would reduce agency conflict (Shleiver and Vishny, 1986; Anderson and Reeb, 2003; Konijn et al., 2011). Thus, the block holder of the company will have positive impact on the firm value. This result indicates that large shareholders do not always generate private benefits (self-oriented) on the cost paid by the minority shareholders. Hence, the result of this research also proves that the agency problem in the conglomerate will be reduced by the existence of block holders.

The existence of block holder, especially the family and the state in the conglomerate, will give positive effect on the firm value both on market performance and financial performance. This breaks the perception of some people where monitoring is less effective in affiliated group company or conglomerate. 
ENTREPRENEURSHIP AND SUSTAINABILITY ISSUES

ISSN 2345-0282 (online) http://jssidoi.org/jesi/ 2019 Volume 7 Number 1 (September) http://doi.org/10.9770/jesi.2019.7.1(5)

Table 4.

Testing Results of Model 1.1

Tobin' $s=\alpha 1+\beta 1$ Famit $+\beta 2$ Instit $+\beta 3$ Stateit $+\beta 4$ Tbkit $+\beta 5$ Sizeit $+\beta 6$ Growthit $+\beta 7$ Ageit $+\varepsilon 1 \ldots(1)$

\begin{tabular}{|c|c|c|c|c|c|c|}
\hline & \multirow{3}{*}{ Prediction } & \multicolumn{5}{|c|}{ Panel A. Research Model Tobin's Q } \\
\hline & & \multicolumn{5}{|c|}{ Cut Off } \\
\hline & & $10 \%$ & $20 \%$ & $30 \%$ & $40 \%$ & $50 \%$ \\
\hline Constant & & $1,22 * * *$ & $0,554 * * *$ & $0,556^{* *}$ & $0,743 * * *$ & $0,427 *$ \\
\hline Fam & $\beta+$ & $-0,119$ & $0,143 * *$ & 0,078 & $0,143 * *$ & $0,254 * * *$ \\
\hline Inst & $\beta+$ & - & $-0,065$ & $-0,098$ & $-0,157 * *$ & - \\
\hline & & $0,243 * * *$ & & & & $0,224 * * *$ \\
\hline State & $\beta+$ & $0,378 * * *$ & $0,637 * * *$ & $0,6^{* * *}$ & $0,659 * * *$ & $0,655 * * *$ \\
\hline Tbk & $\beta+$ & $-0,134^{*}$ & 0,048 & 0,06 & 0,036 & 0,06 \\
\hline Size & $\beta+$ & $-0,01$ & 0,05 & 0,054 & 0,013 & $0,061^{*}$ \\
\hline Growth & $\beta+$ & 0,001 & 0,001 & 0,001 & 0,001 & 0,002 \\
\hline Age & $\beta+$ & $0,031 * * *$ & $0,027 * * *$ & $0,029 * * *$ & $0,035^{* * *}$ & $0,03 * * *$ \\
\hline$F_{\text {stat }}$ & & $11,94 * * *$ & $26,941 * * *$ & $11,96 * * *$ & $13,67 * * *$ & $20,84 * * *$ \\
\hline \multirow[t]{4}{*}{ Adjusted $\mathrm{R}^{2}$} & & 11,46 & $11,11 \%$ & $11,47 \%$ & $13,04 \%$ & $19 \%$ \\
\hline & & \multicolumn{5}{|c|}{ Panel B. Robust Test Tobin's Q } \\
\hline & & \multicolumn{5}{|c|}{ Cut Off } \\
\hline & & $10 \%$ & $20 \%$ & $30 \%$ & $40 \%$ & $50 \%$ \\
\hline Constant & & $1,615^{* * *}$ & $1,29 * * *$ & $1,335^{* * *}$ & $1,368 * * *$ & $1,342 * * *$ \\
\hline Fam & $\beta+$ & $-0,089$ & $0,227 * *$ & $0,189 * * *$ & $0,178 * * *$ & $0,244 * * *$ \\
\hline Inst & $\beta+$ & $-0,24 * * *$ & $-0,075$ & $-0,051$ & $-0,145^{* *}$ & $\begin{array}{l}- \\
0,214 * * *\end{array}$ \\
\hline State & $\beta+$ & $0,348 * * *$ & $0,679 * * *$ & $0,65 * * *$ & $0,618 * * *$ & $0,644 * * *$ \\
\hline Tbk & $\beta+$ & $-0,151^{*}$ & 0,001 & 0,057 & $-0,022$ & 0,005 \\
\hline Size & $\beta+$ & - & - & - & - & - \\
\hline Growth & $\beta+$ & - & - & - & - & - \\
\hline Age & $\beta+$ & - & - & - & - & - \\
\hline $\mathrm{F}_{\text {stat }}$ & & $10,58 * * *$ & $15,17 * * *$ & $13,07 * * *$ & $16,57 * * *$ & $20,79 * * *$ \\
\hline Adjusted $\mathrm{R}^{2}$ & & $6,1 \%$ & $8,72 \%$ & $7,53 \%$ & $9,52 \%$ & $11,78 \%$ \\
\hline
\end{tabular}

Significance $1 \%$, ** Significance $5 \%$, * Significance $10 \%$.

The table above summarizes the results of testing the effect of controlling shareholders consisting of family, financial institutions, state and public company to firm value are proxied by Tobin's Q and Return on Assets, and robust test without using control variables, namely size, growth and age. Controlling shareholder tested on a cut-off of $10 \%-50 \%$ which is the ownership control. Tobin's Q calculated from the market value of the shares plus the book value of debt divided by the book value of assets. Return on Assets is calculated from the company's net profit divided by the book value of assets. The controlling shareholder of using dummy, "1" if the company is controlled by 
a controller (family, institutions, countries and companies tbk); and "0" otherwise. Size is the logarithm of total assets, growth is the growth of the company sales $\Delta$ sales / sales, and age is calculated from the first time the company go public.

Table 5.

Testing Results of Model 1.2

$R O A=\alpha 2+\beta 8$ Famit $+\beta 9$ Instit $+\beta 10$ Stateit $+\beta 11$ Tbkit $+\beta 12$ Sizeit $+\beta 13$ Growthit $+\beta 14$ Ageit $+\varepsilon 2 \ldots(2)$

\begin{tabular}{|c|c|c|c|c|c|c|}
\hline & \multirow[t]{3}{*}{ Predict } & \multicolumn{5}{|c|}{ Panel A. Research Model ROA } \\
\hline & & \multicolumn{5}{|c|}{ Cut Off } \\
\hline & & $10 \%$ & $20 \%$ & $30 \%$ & $40 \%$ & $50 \%$ \\
\hline Constant & & 0,013 & $-0,022$ & $-0,008$ & $-0,011$ & $-0,03 *$ \\
\hline Fam & $\beta+$ & 0,008 & $0,018 * * *$ & $0,008 *$ & $0,015^{* * *}$ & $0,024 * * *$ \\
\hline Inst & $\beta+$ & $-0,027 * * *$ & $-0,013 * *$ & $-0,02 * * *$ & $-0,016 * * *$ & $-0,02 *$ \\
\hline State & $\beta+$ & $0,077 * * *$ & $0,099 * * *$ & $0,09 * * *$ & $0,1 * * *$ & $0,09 * * *$ \\
\hline Tbk & $\beta+$ & 0,006 & $0,013 * *$ & $0,02 * * *$ & $0,036 * * *$ & $0,025 * * *$ \\
\hline Size & $\beta+$ & $-0,002$ & 0,0007 & 0,0003 & $-0,0002$ & 0,002 \\
\hline Growth & $\beta+$ & $-0,0003$ & $-0,0004$ & $-0,0004$ & $-0,0004$ & $-0,0005$ \\
\hline Age & $\beta+$ & $0,004 * * *$ & $0,004 * * *$ & $0,004 * * *$ & $0,004 * * *$ & $0,004 * * *$ \\
\hline $\mathrm{F}_{\text {stat }}$ & & $37,22 * * *$ & $42,24 * * *$ & $47,14 * * *$ & $48,27 * * *$ & 50,03 \\
\hline \multirow[t]{4}{*}{ Adjusted } & & $29,99 \%$ & $32,78 \%$ & $35,3 \%$ & $35,89 \%$ & $36,7 \%$ \\
\hline & & \multicolumn{5}{|c|}{ Panel B. Robust Test ROA } \\
\hline & & \multicolumn{5}{|c|}{ Cut Off (Cut Off) } \\
\hline & & $10 \%$ & $20 \%$ & $30 \%$ & $40 \%$ & $50 \%$ \\
\hline Constant & & $0,067 * * *$ & $0,047 * * *$ & $0,047 * * *$ & $0,048 * * *$ & $0,044 * * *$ \\
\hline Fam & $\beta+$ & $-0,001$ & $0,013 * *$ & $0,011 * *$ & $0,011^{* *}$ & $0,027 * * *$ \\
\hline Inst & $\beta+$ & $-0,033 * * *$ & $-0,017 * * *$ & $-0,015 * * *$ & $-0,015^{* *}$ & $-0,02$ \\
\hline State & $\beta+$ & $0,056 * * *$ & $0,086 * * *$ & $0,08 * * *$ & $0,082 * * *$ & $0,086^{* * *}$ \\
\hline Tbk & $\beta+$ & 0,003 & $0,013 * *$ & $0,022 * * *$ & $0,033 * * *$ & $0,026 * * *$ \\
\hline Size & $\beta+$ & - & - & - & - & - \\
\hline Growth & $\beta+$ & - & - & - & - & - \\
\hline Age & $\beta+$ & - & - & - & - & - \\
\hline $\mathrm{F}_{\text {stat }}$ & & $29,83 * * *$ & $31,88 * * *$ & $39,11 * * *$ & $36,8 * * *$ & $34 * * *$ \\
\hline Adjusted & & $16,28 \%$ & $17,24 \%$ & $20,45 \%$ & $19,48 \%$ & $18,21 \%$ \\
\hline
\end{tabular}

Source: Data processed, 2016

*** Significance $1 \%$, ** Significance 5\%, * Significance $10 \%$.

From four block holders, it is only financial institution that has negative effect on Tobin's Q and Return on Assets at all cut off. This result is consistent with the research result of Khanna and Palepu (1999) arguing that the financial institutions in domestic companies have negative effect on the firm value. The existence of institutional shareholders is not able to monitor conglomerate, instead, it is supposed due to the presence of family block holders and the state which is large in the conglomerate. The result of descriptive analysis supports the result of 
hypothesis testing where the greater cut off, then the smaller the percentage of controlling financial institutions and public companies will be. Yet, the opposite happens to the family block holder and the state, where the higher cut off, the greater percentage of controller is. The expropriation is carried out by the block holder in large companies in Indonesia, particularly by conglomerate to gain private benefits and controls to maximize their own welfare. Although the practice is commonly carried out by large companies through distributing wealth from other parties, it will undermine their reputation. Yet, the practice is proven not to be common for conglomerate in Indonesia.

Table 6.

Testing Results of Model 2.1

Tobin' sQ $i t=\alpha 1+\beta 1$ Pol* Famit $+\beta 2$ Pol $^{*}$ Instit $+\beta 3$ Pol* State it $+\beta 4$ Pol* Tbkit $+\beta 5$ Size it $+\beta 6$ Growth it $+\beta 7$ Age it $+\varepsilon 3 \ldots$...

\begin{tabular}{|c|c|c|c|c|c|c|}
\hline & \multirow[b]{3}{*}{ Prediction } & \multicolumn{5}{|c|}{ Panel A. Research Model (Tobins Q) } \\
\hline & & \multicolumn{5}{|c|}{ Cut Off } \\
\hline & & $10 \%$ & $20 \%$ & $30 \%$ & $40 \%$ & $50 \%$ \\
\hline $\begin{array}{l}\text { Constant } \\
\text { Pol*Fam } \\
\text { Pol*Inst } \\
\text { Pol*State } \\
\text { Pol*Tbk } \\
\text { Size } \\
\text { Growth } \\
\text { Age } \\
\text { Fstat } \\
\text { Adjusted } \mathrm{R}^{2}\end{array}$ & $\begin{array}{l}\beta+ \\
\beta+ \\
\beta+ \\
\beta+ \\
\beta+ \\
\beta+ \\
\beta+\end{array}$ & $\begin{array}{l}0,575^{* *} \\
0,098^{*} \\
-0,129 * \\
0,484^{* * *} \\
-0,049 \\
0,056^{* * *} \\
0,0006 \\
0,028^{* * *} \\
10,346^{* * *} \\
9,95 \%\end{array}$ & $\begin{array}{l}0,575^{* *} \\
0,16^{* * *} \\
-0,058 \\
0,589^{* * *} \\
-0,157 \\
0,06 \\
0,0006 \\
0,024 * * * \\
10,65 * * * \\
10,24 \%\end{array}$ & $\begin{array}{l}0,709 * * * \\
0,167 * * * \\
-0,134 \\
0,607 * * * \\
-0,022 \\
0,036 \\
0,0006 \\
0,027 * * * \\
11,854 * * * \\
11,37 \%\end{array}$ & $\begin{array}{l}0,798 * * * \\
0,263 * * * \\
-0,232 * * \\
0,627 * * * \\
-0,03 \\
0,016 \\
0,0006 \\
0,03 * * * \\
12,92 * * * \\
12,37 \%\end{array}$ & $\begin{array}{l}0,628 * * \\
0,36 * * * \\
-0,236 \\
0,624 * * * \\
-0,016 \\
0,04 \\
0,0009 \\
0,029 * * * \\
14,72 * * * \\
13,96 \%\end{array}$ \\
\hline \multirow{3}{*}{ Adjusted $\mathrm{R}^{2}$} & & \multicolumn{5}{|c|}{ Panel B. Robust Test (Tobins Q) } \\
\hline & & \multicolumn{5}{|c|}{ Cut Off } \\
\hline & & $10 \%$ & $20 \%$ & $30 \%$ & $40 \%$ & $50 \%$ \\
\hline Constant & & $1,365 * * *$ & $1,333 * * *$ & $1,341 * * *$ & $1,352 * * *$ & $1,342 * * *$ \\
\hline Pol*Fam & $\beta+$ & $0,2 * * *$ & $0,274 * * *$ & $0,285^{* * *}$ & $0,347 * * *$ & $0,429 * * *$ \\
\hline Pol*Inst & $\beta+$ & $-0,098$ & $-0,038$ & $-0,084$ & $-0,153 *$ & $-0,213$ \\
\hline Pol*State & $\beta+$ & $0,522 * * *$ & $0,631 * * *$ & $0,654 * * *$ & $0,643 * * *$ & $0,652 * * *$ \\
\hline Pol*Tbk & $\beta+$ & $-0,08$ & $-0,152$ & $-0,005$ & 0,017 & 0,026 \\
\hline Size & $\beta+$ & - & - & - & - & - \\
\hline Growth & $\beta+$ & - & - & - & - & - \\
\hline Age & $\beta+$ & - & - & - & - & - \\
\hline Fstat & & $9,51 * * *$ & $15,11 * * *$ & $16,93 * * *$ & $18,47 * * *$ & $19,6 * * *$ \\
\hline Adjusted $\mathrm{R}^{2}$ & & $5,43 \%$ & $8,69 \%$ & $9,71 \%$ & $10,56 \%$ & $11,15 \%$ \\
\hline
\end{tabular}

Source: Data processed, 2016

$* * *$ Significance $1 \%$, ** Significance $5 \%$, * Significance $10 \%$.

The table above summarizes the results of testing the effect of political connections in various controlling shareholders consisting of family, financial institutions, state and public company to firm value are proxied by Tobin's Q and Return on Assets, and robust test without using control variables, namely size, growth and age. Controlling shareholder tested on cut-off of $10 \%-50 \%$, the control of ownership. Political connections using a dummy, "1" if the conglomerates have political connections; and "0" otherwise. Interaction 
political connection is made to all the variables controlling shareholder (family, institutions, countries and public companies). Return on Assets is calculated from the company's net profit divided by the book value of assets. Size is the logarithm of total assets, growth is the growth of the company sales $\Delta$ sales / sales, and age is calculated from the first time the company go public.

Table 7.

Testing Results of Model 2.2

ROA it $=\alpha 2+\beta 8$ Pol $*$ Famit $+\beta 9$ Pol $*$ Instit $+\beta 10$ Pol $*$ Stateit $+\beta 11$ Pol $*$ Tbkit $+\beta 12$ Sizeit $+\beta 13$ Growthit $+\beta 14$ Ageit $+\varepsilon 4 .$.

\begin{tabular}{|c|c|c|c|c|c|c|}
\hline & \multirow[b]{3}{*}{ Prediction } & \multicolumn{5}{|c|}{ Panel A. Research Model (Return on Assets) } \\
\hline & & \multicolumn{5}{|c|}{ Cut Off } \\
\hline & & $10 \%$ & $20 \%$ & $30 \%$ & $40 \%$ & $50 \%$ \\
\hline Constant & & $-0,009$ & $-0,011$ & $-0,013$ & $-0,02$ & $-0,02$ \\
\hline Pol*Fam & $\beta+$ & $0,01 * *$ & $0,016 * * *$ & $0,015 * * *$ & $0,023 * * *$ & $0,028 * * *$ \\
\hline Pol*Inst & $\beta+$ & $-0,021 * * *$ & $-0,022 * * *$ & $-0,023 * * *$ & $-0,02 * * *$ & $-0,019 *$ \\
\hline Pol*State & $\beta+$ & $0,075 * * *$ & $0,09 * * *$ & $0,088 * * *$ & $0,089 * * *$ & $0,09 * * *$ \\
\hline Pol*Tbk & $\beta+$ & $-0,001$ & $-0,0007$ & 0,007 & $0,018 * *$ & $0,013^{*}$ \\
\hline Size & $\beta+$ & 0,0006 & 0,0003 & 0,001 & 0,002 & 0,001 \\
\hline Growth & $\beta+$ & $-0,0007$ & $-0,0006$ & $-0,0007$ & $-0,0007$ & $-0,0007$ \\
\hline Age & $\beta+$ & $0,004 * * *$ & $0,004 * * *$ & $0,004 * * *$ & $0,004 * * *$ & $0,0037 * * *$ \\
\hline Fstat & & $31,34 * * *$ & $44,29 * * *$ & $46,65 * * *$ & $51,2 * * *$ & $51,57 * * *$ \\
\hline \multirow[t]{4}{*}{ Adjusted $\mathrm{R}^{2}$} & & $26,4 \%$ & $33,86 \%$ & $35,06 \%$ & $37,29 \%$ & $37,42 \%$ \\
\hline & & \multicolumn{5}{|c|}{ Panel B. Robust Test (Return on Assets) } \\
\hline & & \multicolumn{5}{|c|}{ Cut Off } \\
\hline & & $10 \%$ & $20 \%$ & $30 \%$ & $40 \%$ & $50 \%$ \\
\hline Constant & & $0,051 * * *$ & $0,047 * * *$ & $0,047 * * *$ & $0,046 * * *$ & $0,047 * * *$ \\
\hline Pol*Fam & $\beta+$ & $0,011 * *$ & $0,018 * * *$ & $0,021 * * *$ & $0,03 * * *$ & $0,036 * * *$ \\
\hline Pol*Inst & $\beta+$ & $-0,015^{* *}$ & $-0,013 * *$ & $-0,01 *$ & $-0,01$ & $-0,017 *$ \\
\hline Pol*State & $\beta+$ & $0,065 * * *$ & $0,086 * * *$ & $0,084 * * *$ & $0,085^{* * *}$ & $0,084 * * *$ \\
\hline Pol*Tbk & $\beta+$ & 0,003 & $-0,003$ & 0,01 & $0,024 * * *$ & $0,016^{* *}$ \\
\hline Size & $\beta+$ & - & - & - & - & - \\
\hline Growth & $\beta+$ & - & - & - & - & - \\
\hline Age & $\beta+$ & - & - & & - & - \\
\hline Fstat & & $15,35^{* * *}$ & $31,47 * * *$ & $33,9 * * *$ & $37,61 * * *$ & $39,81 * * *$ \\
\hline Adjusted $\mathrm{R}^{2}$ & & $8,83 \%$ & $17,05 \%$ & $18,16 \%$ & $19,83 \%$ & $20,75 \%$ \\
\hline
\end{tabular}

Source: Data processed, 2016

*** Significance $1 \%$, ** Significance 5\%, * Significance $10 \%$.

Based on the result test of second hypotheses model testing presented in Table 6 and 7, it shows that political connection in the state and family-controlled companies have significant positive effect on Tobin's Q and Return on Assets at all cut off from $10 \%$ to $50 \%$, while the political connections in the companies controlled by institutions have negative affect on Tobin's Q and Return on Assets at all cut off from 10\% to 50\%. Political connections in the companies controlled by the public company have positive effect only on Return on Assets at the cut off $40 \%$ and $50 \%$ only. Based on the results of standardized regression analysis (in appendix), the effect of political connections on companies controlled by the state have greater effect on the firm value both in Tobinn's Q 


\section{ENTREPRENEURSHIP AND SUSTAINABILITY ISSUES}

ISSN 2345-0282 (online) http://jssidoi.org/jesi/ 2019 Volume 7 Number 1 (September) http://doi.org/10.9770/jesi.2019.7.1(5)

and Return on Assets in all cut off from $10 \%$ to $50 \%$ compared to other controllers (family, institutional or public company). The result of of third model testing is consistent with robustness test which indicates that that the third research model is robust or sturdy.

This result is consistent with the finding of Boubakri et al. (2008) in which they found that political connection in the company is positively related to government ownership. Likewise, Tian and Cheung (2013) found that political connection can increase the firm value which is controlled by family. Political connection proves to be able to obtain government protection, such as greater amount of bank loans, long-term credit, lower real effective tax rate as well as greater government subsidies.

The result of this research indicates that the structure of companies ownership have contribution to determine the political connections in the conglomerate. The family block holder and the state in the company with political connection, tend to dominate the board of commissioners so that they can make a deal with government officer to obtain the exclusive benefit from them (Chen et al., 2011).

The test result of political connections on the companies which are controlled by the public ownership do not have effect on Tobin's Q at all cut off from $10 \%$ to $50 \%$. Neither do it have effect on the ROA at cut off from $10 \%$ to $30 \%$. But, at the cut off $40 \%$ and $50 \%$, political connections with the control of public company have positive effect on Return on Assets. It shows that political connection in the public company has positive effect on firm value only at major ownerships (majority shareholder) so that it has a greater control on the decisions making. Meanwhile, political connections in the companies controlled by financial institutions have negative effect on both the Tobins'Q and ROA at the all cut off from $10 \%$ to $50 \%$. This results show that financial institutions in the conglomerate are not able to control the company, so that political connections cannot affect the firm value.

The results of present study revealed that political connection on the controlling family, state, and public companies has positive effect on the firm value in conglomerate in Indonesia. These results support the finding of Tian and Cheung (2013), where they only found positive effect of political connection on the controlling family. Given that the third hypothesis about the influence of political connections on companies controlled by the family, the State and public companies is clearly evidenced. As such, it implies that the controlling company can easily control the other parties and determine policies which provide benefit for them. They are also free to determine who may eventually occupy board of commissioners, an independent commissioner or chairman of commissioner who can provide benefits for their interests and companies. Thus, it is not surprising that the position of commissioners which has very vital function for a company is occupied by retired generals, high officials of state, both active and non-active government officials who lack of competence in their field. This finding is in line with the statement of Winters (2014), arguing that Indonesia is already falling into oligarchy, where the government is occupied by a group of wealthy political elites.

Oligarchy in Indonesia adjusts quickly to the new regime. When the old regime ("orde lama or old order") collapsed, the oligarchs in Indonesia adjusted quickly to the new regime (so-called "new order"). Through the process of transition and adaptation, Indonesia oligarchy held the power and had a good luck for more than 30 years under Suharto's administration. The greatest change in oligarchies during the new orde was that networks had become very rich elite and therefore its power resources also increased sharply. When the "new order" fell, oligarchs adapted itself to this era of reform for several weeks in 1998 and quickly turned into the time of restoration for the oligarchy. Oligarchy (elite network) in Indonesia persisted and had a high ability to adapt whenever there were changes in the shape, structure, or other government agencies (Winters, 2004). 


\section{ENTREPRENEURSHIP AND SUSTAINABILITY ISSUES}

ISSN 2345-0282 (online) http://jssidoi.org/jesi/ 2019 Volume 7 Number 1 (September) http://doi.org/10.9770/jesi.2019.7.1(5)

\section{Conclusions}

The results study on the effect of family block holder, the state and public companies on firm value (Tobin's Q \& ROA), showed that the presence of large shareholders in the company motivates them to perform better monitoring of the management. The study also proved that a large shareholder at a rate higher ownership has a positive effect on firm value. Accumulated or concentrated ownership can serve as a corporate governance mechanism to better and more effectively monitor the management that would reduce conflicts of agency (Shleiver and Vishny, 1986; Anderson and Reeb, 2003; Konijn et al., 2013). Hence, the block holder of the company will have a positive impact on firm value.

The presence of political connection at the state and family-controlled company has positive effect on the firm value (Tobin's Q \& ROA) at all cut off. It indicates that the ownership structure of companies has contribution to determine the political connections in the conglomerate. The family block holder and the state which have political connection, tend to dominate the board of commissioners so that they can make a deal with government officer and obtain the privileges from them (Chen et al., 2011).

The concentration of ownership in the company and family as controlling highest conglomerate in Indonesia as well as their involvement in politics implies that Indonesia has fallen into oligarchy state, in which the rules are held by a group of wealthy political elites. Various cases of bribery are widespread among the businessmen and the authorities in many cases. It leads to high-cost in economy, inefficiency and misallocation of the nation's resources, unfair competition, and disharmony in the social life which may reduce public confidence in the country and worsen the image of Indonesia in the international communities.

\section{References}

Ang, J.S., Ding, D.K. and Thong, T.Y. 2013. Political Connection and Firm Value. Asian Development Review, Vol. 30 (2), pp. $131-166$. http://hdl.handle.net/11540/1620

Arifin, Zaenal. 2003. Agency Problems and Mechanism of Company Control with Concentrated Ownership Structure Controlled Families: Evidence from a Public Company in Indonesia, Dissertation, Graduate Program, University of Indonesia: Depok. Retrieved from Library of University Indonesia. http://lib.ui.ac.id/

Anderson, R.C. and Reeb, D.M. 2003. Founding-family ownership and firm performance: evidence from the S\&P 500. The Journal of Finance, 58(3), pp.1301-1328. https://doi.org/10.1111/1540-6261.00567

Boubakri, N., Cosset, J.C. and Saffar, W. 2008. Political connections of newly privatized firms. Journal of Corporate Finance, 14(5), pp.654-673. https://doi.org/10.1016/j.jcorpfin.2008.08.003

Chaney, P.K., Faccio, M. and Parsley, D. 2011. The quality of accounting information in politically connected firms. Journal of Accounting and Economics, 51(1-2), pp.58-76. https://doi.org/10.1016/j.jacceco.2010.07.003

Chen, C.J., Li, Z., Su, X. and Sun, Z. 2011. Rent-seeking incentives, corporate political connections, and the control structure of private firms: Chinese evidence. Journal of Corporate Finance, 17(2), pp.229-243. https://doi.org/10.1016/j.jcorpfin.2010.09.009

Claessens, S., Djankov, S. and Lang, L.H. 2000. The separation of ownership and control in East Asian corporations. Journal of Financial Economics, 58(1-2), pp.81-112. https://doi.org/10.1016/S0304-405X(00)00067-2

Cooper, M.J., Gulen, H. and Ovtchinnikov, A.V. 2010. Corporate political contributions and stock returns. The Journal of Finance, 65(2), pp.687-724. https://doi.org/10.1111/j.1540-6261.2009.01548.x

Deng, X., Tian, Z., Li, J. and Abrar, M. 2012. The diversification effects of a firm's political connection and its performance implications: Evidence from China. Chinese Management Studies, 6(3), pp.462-487. https://doi.org/10.1108/17506141211259140

Dicko, S. 2017. Political connections, ownership structure and quality of governance. International Journal of Managerial Finance, 13(4), pp.358-377. https://doi.org/10.1108/IJMF-01-2017-0010

Do, Q.A., Lee, Y.T. and Nguyen, B.D. 2015. Political connections and firm value: Evidence from the regression discontinuity design of close gubernatorial elections. http://dx.doi.org/10.2139/ssrn.2023191

Faccio, M., Lang, L.H. and Young, L. 2001. Dividends and expropriation. American Economic Review, 91(1), pp.54-78. http://dx.doi.org/10.1257/aer.91.1.54

Faccio, M. 2006. Politically connected firms. American Economic Review, 96(1), pp.369-386. http://dx.doi.org/10.1257/000282806776157704

Fan, J. P., Wong, T. J., \& Zhang, T. 2007. Politically Connected CEOs, Corporate Governance, and Post-IPO Performance of China's Newly Partially Privatized Firms. Journal of Financial Economics, 84(2), pp. 330-357. https://doi.org/10.1016/j.jfineco.2006.03.008 


\section{ENTREPRENEURSHIP AND SUSTAINABILITY ISSUES}

ISSN 2345-0282 (online) http://jssidoi.org/jesi/ 2019 Volume 7 Number 1 (September) http://doi.org/10.9770/jesi.2019.7.1(5)

Fisman, R., 2001. Estimating the value of political connections. American Economic Review, 91(4), pp.1095-1102. http://dx.doi.org/10.1257/aer.91.4.1095

Goldman, Eitan, Jorg Rocholl, dan Jongil So. 2009. Do Politically Connected Boards Affect Firm Value? Review of Financial Studies 22, pp. 2331-2360. https://doi.org/10.1093/rfs/hhn088

Isik, O. and Soykan, M.E. 2013. Large shareholders and firm performance: Evidence from Turkey. European Scientific Journal, ESJ, 9(25). Pp. 23-37. http://dx.doi.org/10.19044/esj.2013.v9n25p\%25p

Jensen, M. C., \& Meckling, W. H. 1976. Theory of the firm: Managerial behavior, agency costs and ownership structure. Journal of Financial Economics, 3(4), pp. 305-360. https://doi.org/10.1016/0304-405X(76)90026-X

Johnson, S. and Mitton, T. 2003. Cronyism and capital controls: evidence from Malaysia. Journal of financial Economics, 67(2), pp.351382. https://doi.org/10.1016/S0304-405X(02)00255-6

Khanna, Tarun and Krishna Palepu. 1999. Emerging Market Business Groups, Foreign Investors, and Corporate Governance, National Bureau of Economic Research Working Paper, Retrieved from http://www.nber.org/papers/w6955.

Kim, Sung Suk. 2006. Simultaneous Relationship between Ownership Structure, Corporate Governance, and Firm Values from the Jakarta Stock Exchange. Dissertation, Graduate Program, University of Indonesia: Depok. Retrieved from Library of University Indonesia. https://doi/org/10.21002/seam.v2i1.5572

Konijn, S.J., Kräussl, R. and Lucas, A. 2011. Blockholder dispersion and firm value. Journal of Corporate Finance, 17(5), pp.1330-1339. https://doi.org/10.1016/j.jcorpfin.2011.06.005

La Porta, R., Lopez-de-Silanes, F. and Shleifer, A. 1999. Corporate ownership around the world. The Journal of Finance, 54(2), pp.471517. https://doi.org/10.1111/0022-1082.00115

Leuz, C. and Oberholzer-Gee, F. 2006. Political relationships, global financing, and corporate transparency: Evidence from Indonesia. Journal of Financial Economics, 81(2), pp.411-439. https://doi.org/10.1016/j.jfineco.2005.06.006

Li, W., He, A., Lan, H. and Yiu, D. 2012. Political connections and corporate diversification in emerging economies: Evidence from China. Asia Pacific Journal of Management, 29(3), pp.799-818. https://link.springer.com/article/10.1007/s10490-011-9265-5

Li, A., dan Xia, X. 2013. Political connections, financial crisis and firm's value: Evidence from Chinese Listed Firms. International Journal of Business and Management, 8(18), pp. 63. https://doi.org/10.5539/ijbm.v8n18p63

Lukviarman, N., 2004. Ownership structure and firm performance: the case of Indonesia. Doctoral dissertation. Curtin University. Retrieved from https://espace.curtin.edu.au/handle/20.500.11937/1268

Niessen, A. and Ruenzi, S. 2010. Political connectedness and firm performance: Evidence from Germany. German Economic Review, 11(4), pp.441-464. https://doi.org/10.1111/j.1468-0475.2009.00482.x

Pirzada, K. 2016. Providers and Users' Perception Of Voluntary Need Of Human Resource Disclosure: A Content Analysis. Polish Journal of Management Studies, 14(2), pp.232-242. https://doi.org/10.17512/pjms.2016.14.2.22

Pirzada, K., Mustapha, M.Z.B. and Wickramasinghe, D. 2015. Firm Performance, Institutional Ownership and Capital Structure: A Case of Malaysia. Procedia-Social and Behavioral Sciences, 211, pp.170-176. https://doi.org/10.1016/j.sbspro.2015.11.025

Siregar, B., 2008. Expropriation of minority shareholders in the ultimate ownership structure. Jurnal Riset Akuntansi Indonesia, 11(3), pp.237-263.

Shleifer, A. and Vishny, R.W. 1986. Large shareholders and corporate control. Journal of Political Economy, 94(3, Part 1), pp.461-488. https://www.journals.uchicago.edu/doi/abs/10.1086/261385

Shleifer, A. and Vishny, R.W. 1997. A survey of corporate governance. The Journal of Finance, 52(2), pp.737-783. https://doi.org/10.1111/j.1540-6261.1997.tb04820.x

Tian, L. and Cheung, W. 2013. Political Connections, Controlling Shareholders and Post-IPO Performance of China's Listed Companies. Institute of Finance and Development. Nankai University. Retrieved from https://web.iss.utokyo.ac.jp/kyoten/activities/paper_April24th.pdf

Wati, M. L. N., Primiana, I., \& Sudarsono, R. 2015. Political connections and controlling shareholder on Indonesia conglomerates. Proceedings of International Conference on Advanced Research Business and Social Sciences (ICARBSS) 2015 Kuala Lumpur, Malaysia, pp 133-142. http://www.academia.edu/download/41317352/PROCEEDINGS_ICARBSS-2015.pdf\#page=133

Wati, L.N., Rachmat Sudarsono, S.E., Si, M. and Erie Febrian, S.E. 2016. Corporate governance on conglomerates pollitically connected. International Journal of Business, Economics and Law, 10(1), pp.23-31.

Wati, L.N., Primiana, I. and Sudarsono, R. 2016. Political connections of conglomerates: evidence form Indonesia Stock Exchange. Actual Problems of $\quad$ Economics, (12), pp.110-119. http://www.irbis-nbuv.gov.ua/cgibin/irbis nbuv/cgiirbis 64.exe?I21DBN=LINK\&P21DBN=UJRN\&Z21ID=\&S21REF=10\&S21CNR=20\&S21STN=1\&S21FMT= ASP_meta\&C21COM=S\&2_S21P03=FILA=\&2_S21STR=ape_2016_12_14

Wati, L. N. 2017. Board of commissioner's effectiveness on politically connected conglomerates: Evidence from Indonesia. Pertanika Journal Social Sciences \& Humanities, 25(S), pp. 255-270. http://www.pertanika.upm.edu.my/view archives.php?journal=JSSH25-S-11

Winters, A., Jeffrey. 2004. Orba jatuh, Orba bertahan? Indonesia. Djambatan Publisher. https://www.scholars.northwestern.edu/en/publications/orba-jatuh-orba-bertahan-indonesias-new-order-falls-endures-an-an

Winters, A., Jeffrey. 2014. Democracy under Clutches Oligarchy. Edisi Vol.33 No. 1. Indonesia. Majalah Prisma.

Wiwattanakantang, Y., 2001. Controlling shareholders and corporate value: Evidence from Thailand. Pacific-Basin Finance Journal, 9(4), pp.323-362. https://doi.org/10.1016/S0927-538X(01)00022-1 


\section{ENTREPRENEURSHIP AND SUSTAINABILITY ISSUES}

ISSN 2345-0282 (online) http://jssidoi.org/jesi/ 2019 Volume 7 Number 1 (September) http://doi.org/10.9770/jesi.2019.7.1(5)

Wong, S.H.W. 2010. Political connections and firm performance: The case of Hong Kong. Journal of East Asian Studies, 10(2), pp.275314. https://doi.org/10.1017/S1598240800003465

Wu, W., Wu, C., Zhou, C. and Wu, J. 2012. Political connections, tax benefits and firm performance: Evidence from China. Journal of Accounting and Public Policy, 31(3), pp.277-300. https://doi.org/10.1016/j.jaccpubpol.2011.10.005

\section{Aknowledgements}

The author thank to STIE Muhammadiyah Jakarta Indonesia for providing Seminar of Foreign Affairs Grant and support of this publication. We thank to Directorate of General for Strengthening Research and Development, the Ministry of Research and Technology Republic Indonesia, Higher Education (DIKTI) for providing Doctoral Scholarship

Dr. Lela Nurlaela WATI, MM is an Associate Professor of STIE Muhammadiyah Jakarta, Indonesia. Her work has attracted best research paper awards in Indoneisa and Malaysia. She is currently reviewer an Economics Business. Her publication have appeared in various International journals, such as Pertanika Journal of Social Sciences and Humanities, Actual Problems of Economics, Internatioanal Journal of Business Economics and Law, South East Asia Journal of Business Economics and Law.

ORCID ID: https://orcid.org/0000-0001-7046-612X

Prof. Dr. Hj. Ina PRIMIANA, SE., MT is the Professor of Economics and Business Faculty of Universitas Padjadjaran Bandung, and a director of STIE Ekuitas Bandung, Indonesia. Her publication have appeared in various International journals, such as Actual Problems of Economics, etc.

Author ID: 55437876800

Kashan PIRZADA, Dr. is a Senior lecturer in Tunku Puteri Intan Safinaz School of Accountancy, Universiti Utara Malaysia, Malaysia. He has been a lead guest editor for Elsevier Procedia of Social and Behavioural Sciences, Pertanika of Social Sciences and Humanities, and International Journal of Economics and Management. His publications have appeared in various International academic journals, such as Elsevier Journal of Social and Behavioural Sciences, British Accounting and Finance; Polish Journal of Management Studies; Pertanika Journal of Social Sciences and Humanities, and International Journal of Economics and Management.

ORCID ID: https://orcid.org/0000-0003-1186-0631

Dr. Rachmat SUDARSONO, M.Si is a senior lecturer of Economics and Business Faculty of Universitas Padjadjaran Bandung, Indonesia. His publication have appeared in various International journals, such as Actual Problems of Economics, etc.

Author ID: 56820254000

Copyright (C) 2019 by author(s) and VsI Entrepreneurship and Sustainability Center

This work is licensed under the Creative Commons Attribution International License (CC BY).

http://creativecommons.org/licenses/by/4.0/

(c) (i) Open Access 